\title{
ЕМПІРИЧНІ РЕФЕРЕНТИ ЕМОЦІЙНОЇ БЕЗПЕКИ ПРОФЕСІОНАЛА
}

\author{
Лазорко Ольга \\ Волинський національний університет імені Лесі Українки, \\ Луцьк, Україна, lazorko.olha@ vnu.edu.ua \\ https://orcid.org/0000-0002-8427-5049

\section{Шевцова Тетяна} \\ Волинський національний університет імені Лесі Українки, \\ Луцьк, Україна, tanechka.shevcova@gmail.com \\ https://orcid.org/0000-0002-6980-2330
}

Mema. У статті визначено місце емоційної безпеки в структурі професійної безпеки особистості, а також емпіричних референтів емоційної безпеки. Важливе завдання - визначення зв'язків загального емоційного фону та схильності до стресу із самооцінкою й професійним вигоранням за трьома шкалами, такими як емоційне виснаження, деперсоналізація та редукція особистих досягнень. Ми припускаємо, що емоційна безпека особистості пов'язана зі специфікою професійної діяльності - роботою з людьми або документами, керівною діяльністю тощо.

Методи. Для вивчення психологічних особливостей прояву емоційної безпеки особистості, зокрема таких емпіричних референтів, як схильність до стресу, емоційна виснаженість, деперсоналізація, редукція професійних досягнень, вираженість базових емоцій та рівень самооцінки, нами використано такі психодіагностичні методики: «Визначення ступеня схильності до стресу» (за Є. О. Тарасовим); «Професійне вигорання» (за К. Маслач, С. Джексон в адаптації Е. Водоп'янової); «Шкала диференціальних емоцій» (за К. Ізардом); «Визначення рівня своєї самооцінки» (за Г. М. Казанцевою).

Результати. Емоційну безпеку професіонала розглянуто як почуття впевненості щодо володіння внутрішніми психологічними ресурсами для протистояння загрозам і небезпекам, пов'язаним із професійною діяльністю. 3 одного боку, емоційна безпека професіонала підтримується внутрішніми психологічними ресурсами, а з іншого - безпечним середовищем і довірливими стосунками в організації. Якщо розглянути ресурси емоційної безпеки крізь призму небезпеки, то схильність до стресу, емоційний фон, рівень професійного вигорання та рівень самооцінки гіпотетично можуть бути тими емпіричними референтами, які дають змогу виявити наявність чи відсутність цих ресурсів. Представлено результати дослідження, мета якого - вивчення зв'язку схильності до стресу та загального емоційного фону з рівнем самооцінки й професійним вигоранням. Доведено, що стан емоційної безпеки пов'язаний не стільки 3

ISSN 2308-3743 (Online), ISSN 2227-1376 (Print)

(C) Лазорко О., Шевцова Т., 2020. Ця стаття відкритого доступу на умовах CC BY-NC 4.0 
психологічними особливостями досліджуваних, скільки зі специфікою провідної професійної діяльності: роботою $з$ документами, роботою 3 людьми, змішаною формою (люди та документи), а також керівною діяльністю.

Висновки. Установлено значимі статистичні взаємозв'язки між показниками базових емоцій та даними професійного вигорання (емоційне виснаження, деперсоналізація, редукція професійних досягнень) і рівнем самооцінки та між показниками професійного вигорання й стресостійкістю, рівнем самооцінки працівників комерційної організації. Подальше вивчення феномену емоційної безпеки особистості професіонала вбачаємо в контексті організаційного середовища та міжособистісної взаємодії персоналу організації. Важливим завданням і викликом для організаційних психологів сьогодні $є$ віднайдення ефективних інструментів та програм забезпечення емоційної стабільності й безпеки персоналу на робочому місці, що, безумовно, $\epsilon$ перспективним напрямом подальших досліджень.

Ключові слова: безпека особистості, професійна діяльність, схильність до стресу, самооцінка, базові емоції, професійне вигорання.

\section{Lazorko Olha, Shevtsova Tetiana. Empirical Referents of Professionals'} Emotional Safety. Purpose. The article proposes to determine the place of emotional safety in the structure of professional security of the individual, as well as empirical reviewers of emotional safety. An important task is to identify the links between the general emotional background and the tendency to stress with self-esteem and burnout on three scales: emotional exhaustion, depersonalization and reduction of personal achievements; we assume that the emotional safety of the individual is related to the specifics of professional activities: working with people or with documents, management activities.

Methods. In order to study the psychological features of the manifestation of emotional safety of the individual, including such empirical referents as stress, emotional exhaustion, depersonalization, reduction of professional achievements, expression of basic emotions and self-esteem, we used the following psychodiagnostic techniques: «Determining the degree of stress» by E. Tarasov); «Professional burnout» (by K. Maslach, S. Jackson in the adaptation of E. Vodopyanova); «Scale of differential emotions» (according to K. Izard); «Determining the level of self-esteem» (according to G. Kazantseva).

Results. The emotional safety of a professional is seen as a sense of confidence in possession of internal psychological resources to confront the threats and dangers associated with professional activities. On the one hand, the emotional safety of a professional is supported by internal psychological resources, and on the other hand, a safe environment and trust in the organization. The propensity to stress, emotional background, level of burnout and self-esteem can hypothetically be the empirical referents that will identify the presence or absence of these resources. The results of a study aimed at examining the relationship between stress propensity and general emotional background with the level of self-esteem and burnout are presented. It is proved that the state of emotional safety is associated not so much with the 
psychological characteristics of the subjects, but with the specifics of the leading professional activity: working with documents, working with people, mixed form (people and documents), as well as leadership.

Conclusions. There are significant statistical relationships between indicators of basic emotions and indicators of burnout (emotional exhaustion, depersonalization, reduction of professional achievements) and the level of self-esteem and between indicators of burnout and stress and self-esteem of employees. Further study of the phenomenon of emotional safety of the professional's personality is seen in the context of the organizational environment and interpersonal interaction of the organization's staff. An important task and challenge for organizational psychologists today is to find useful tools and programs to ensure the emotional stability and safety of staff in the workplace, which is certainly a promising area of further research.

Key words: personal safety, professional activity, propensity to stress, selfesteem, basic emotions, professional burnout.

Лазорко Ольга, Шевцова Татьяна. Эмпирические референты эмоциональной безопасности профессионала. Цель. В статье определяется место эмоциональной безопасности в структуре профессиональной безопасности личности, а также эмпирические референты эмоциональной безопасности. Важная задача - установление связей общего эмоционального фона и склонности к стрессу с самооценкой и профессиональным выгоранием по трем шкалам: эмоциональное истощение, деперсонализация и редукция личных достижений. Мы предполагаем, что эмоциональная безопасность личности связана со спецификой профессиональной деятельности: работой с людьми или документами, руководящей деятельностью.

Memodb. С целью изучения психологических особенностей проявления эмоциональной безопасности личности, в частности таких эмпирических референтов, как склонность к стрессу, эмоциональная усталость, деперсонализация, редукция профессиональных достижений, выраженность базовых эмоций и уровень самооценки, нами использовались такие психодиагностические методики: «Определение степени склонности к стрессу» (Е. А. Тарасов) «Профессиональное выгорание» (К. Маслач, С. Джексон в адаптации Е. Водопьяновой), «Шкала дифференциальных эмоций» (К. Изард), «Определение уровня своей самооценки» (М. Казанцев).

Результаты. Эмоциональная безопасность профессионала рассматривается как чувство уверенности, обусловленное внутренними психологическими ресурсами, для противостояния угрозам и опасностям, связанным с профессиональной деятельностью. С одной стороны, эмоциональная безопасность профессионала поддерживается внутренними психологическими ресурсами, а с другой - безопасной средой и доверительными отношениями в организации. Если рассмотреть ресурсы эмоциональной безопасности сквозь призму опасности, то склонность к стрессу, эмоциональный фон, уровень профессионального выгорания и уровень самооценки гипотетически могут быть теми эмпирическими референтами, которые позволят выявить наличие или отсутствие этих 
ресурсов. Представлены результаты исследования, целью которого было изучение связи склонности к стрессу и общего эмоционального фона с уровнем самооценки и профессиональным выгоранием. Доказывается, что состояние эмоциональной безопасности связано не столько с психологическими особенностями испытуемых, сколько со спецификой ведущей профессиональной деятельности: работой с документами, работой с людьми, смешанная форма (люди и документы), а также руководящей деятельностью.

Bbыводы. Установлены значимые статистические взаимосвязи между показателями базовых эмоций и показателями профессионального выгорания и уровнем самооценки и между показателями профессионального выгорания и стрессоустойчивости и уровнем самооценки работников коммерческой организации. Дальнейшее изучение феномена эмоциональной безопасности личности профессионала видится в контексте влияния организационной среды и межличностного взаимодействия персонала организации. Важной задачей и вызовом для организационных психологов сегодня является нахождение эффективных инструментов и создание программ обеспечения эмоциональной стабильности и безопасности персонала на рабочем месте, что, безусловно, является перспективным направлением дальнейших исследований.

Ключевые слова: безопасность личности, профессиональная деятельность, склонность к стрессу, самооценка, базовые эмоции, профессиональное выгорание.

Вступ. Сучасна ситуація загроз і ризиків ставить підвищені вимоги до психологічної стійкості особистості, психологічної готовності до невизначеності, психологічних ресурсів для підтримання стану безпеки та рівноваги.

Пандемія Ковід-19 викликає серйозне занепокоєння не лише щодо фізичного, але й психічного здоров'я населення. Страх і невизначеність, високі ризики та небезпеки посилюються через тиск на людей, пов'язаний із роботою. До недавнього часу було прийнято вважати, що в процесі виконання професійної діяльності людина повинна керуватися переважно свідомими міркуваннями, логікою й раціональною поведінкою. Проте новітні дослідження неврології та фізіології доводять, що на наше сприйняття, ставлення й вибір поведінкових стратегій впливають як пізнання, так і емоції, і часто саме останні мають більший вплив. Відчуття емоційної безпеки та комфорту на робочому місці сьогодні стає життєвою необхідністю й бажаним станом, який впливає на загальне психологічне самопочуття працівника та його емоційне здоров'я, а отже, на його продуктивність і результативність у роботі. 
Одним із перших учених, ім'я якого згадується щодо поняття «емоційна безпека», був Вільям Блатц (1966), який усю поведінку індивіда у всіх сферах життєдіяльності розглядав у термінах безпеки, яка визначалася як почуття свободи від небезпеки, як суб'єктивне відчуття, що грунтується на досвіді подолання попередніх небезпек, а також на вмінні передбачити та прогнозувати майбутні наслідки власних виборів. Отже, безпеку визначають переживання теперішнього й майбутнього. В. Блатц прирівнював безпеку до почуття впевненості та ефективності, незважаючи на обставини. На думку Е. Еріксона (1968), саме криза першого року життя формує в дитини базове почуття довіри до світу, яке, зрештою, і формує відчуття емоційної безпеки як психологічний стан, у той час як можливість катастрофи, що нависла над людством сьогодні, порушує той закладений у людині глибинний шар «базисної довіри до світу». У подальших наукових пошуках сплеск інтересу до проблем безпеки спостерігаємо в кінці XX ст., коли під впливом техногенних катастроф почала формуватися філософія «суспільства ризику» (У. Бек (2000), а вітальне значення безпеки набуло небачених масштабів. Ізраільський психолог Д. Бар-Таль (1998) розглядає психологічну небезпеку в контексті уявлень. Уявлення про безпеку формуються індивідуально і є суб' єктивним відображенням реальності. Уявлення про безпеку формуються на основі взаємодії інформації, що поступає 3 навколишнього середовища, й особистих характеристик. Так, почуття безпеки людини виділяється його демографічними, соціально-економічними характеристиками та особистим досвідом. Інтерпретація емоційної безпеки через почуття впевненості людини у володінні внутрішніми ресурсами для протистояння загрозам і небезпечним ситуаціям представлена в роботі П. Девіса та Е. Каммінгса (1994). Важливим висновком є, на нашу думку, твердження, що емоційна безпека - це почуття прийняття, упевненості, що ви перебуваєте в правильному місці, в оточенні потрібних людей. Низка психологічних досліджень мала на меті простежити вплив ранніх стосунків із батьками та оточенням на формування емоційної безпеки як психологічної властивості особистості, яка пов'язана із самооцінкою і Я-концепцією (Little M., Kobak R. (2003), Mikulincer, M. (1998), Рубцов С., Березина Т. Н. (2013)). Бачення емоційної безпеки як компонента психологічної безпеки особистості (Зотова О. Ю. (2011), Закс, Л. А. (2012), Агузумцян Р. В. (2009)) дало змогу зрозуміти важливість саме емотивного компонента формування суб'єктивного стану безпеки. 
На окрему увагу заслуговують дослідження стосовно психологічних аспектів безпеки особистості на робочому місці. Дослідження на цю тему в основному стосувались організаційного рівня розгляду (Christopher J. Collins and Ken G. Smith (2006), Edmondson, A. (1999), H. Leroy, B. Dierynck, F. Anseel and T. Simons (2012)). Психологічна безпека описується як уявлення про наслідки прийняття особистісних ризиків під час роботи, що впливає на готовність індивіда «виражати себе фізично, когнітивно та емоційно під час командної роботи» (Edmondson, A. C., \& Lei, Z. (2014)), при чому це не означає затишного середовища й відсутності проблем і стресів. Швидше, це описує клімат, який орієнтований на продуктивну дискусію задля досягнення цілей (M. Baer and M. Frese (2003), May, D. R. (2004), R. Law, M. Dollard, M. Tuckey and C. Dormann (2011). У вітчизняній психології питання емоційної безпеки в контексті психологічної безпеки розглядаються в працях О. Лазорко (2016) - щодо безпеки особистості як суб'єкта професіоналізації, І. Приходько (2013) - стосовно психологічної безпеки персоналу екстремальних видів діяльності, А. Харченко (2012) - стосовно психологічної безпеки викладачів, О. Блинової (2018) - щодо психологічної безпеки студентів, яка розуміється як «захищеність особистості, породжувана суб'єктивним сприйняттям себе у світі, суб'єктивною оцінкою своєї життєдіяльності з погляду іiі підконтрольності».

Отже, емоційну безпеку професіонала можна розглядати як почуття впевненості щодо володіння внутрішніми психологічними ресурсами для протистояння загрозам і небезпекам, пов'язаним із професійною діяльністю. Отже, з одного боку, емоційна безпека професіонала підтримується завдяки внутрішнім психологічним ресурсам, а 3 іншого - безпечним середовищем і довірливими стосунками в організації. Якщо розглянути ресурси емоційної безпеки через крізь небезпеки, то схильність до стресу, емоційний фон, рівень професійного вигорання та рівень самооцінки гіпотетично можуть бути тими емпіричними референтами, які дадуть змогу виявити наявність чи відсутність цих ресурсів.

Мета нашого дослідження - визначення місця емоційної безпеки в структурі професійної безпеки особистості, а також емпіричних референтів емоційної безпеки. Важливим завданням вважаємо визначення зв'язків загального емоційного фону та схильності до стресу із самооцінкою та професійним вигоранням за трьома шкалами, як-от: 
емоційне виснаження, деперсоналізація й редукція особистих досягнень. Окрім того, ми припускаємо, що емоційна безпека особистості пов'язана зі специфікою професійної діяльності - роботою з людьми або документами, керівною діяльністю тощо.

Методи та процедура дослідження. Дослідження емоційної безпеки особистості проводили протягом вересня-жовтня 2020 р. на базі товариства $з$ обмеженою відповідальністю керуючої компанії «Континіум» серед працівників персоналу автозаправних комплексів «WOG». Вибірку становило 40 працівників організації, яких розподілено на чотири категорії відповідно до специфіки та типу роботи (робота 3 документами, робота 3 людьми, змішана група (у професійній діяльності яких поєднуються різні види роботи), робота на керівних посадах). Проведений у подальшому кореляційний аналіз дав змогу визначити міру зв'язку між досліджуваними явишами.

Із метою вивчення психологічних особливостей прояву емоційної безпеки особистості, зокрема таких емпіричних референтів, як схильність до стресу, емоційна виснаженість, деперсоналізація, редукція професійних досягнень, вираженість базових емоцій та рівень самооцінки, нами використано психодіагностичні методики, як-от: «Визначення ступеня схильності до стресу» (за Є. О. Тарасовим); «Професійне вигорання» (за К. Маслач, С. Джексон в адаптації Е. Водоп’янової); «Шкала диференціальних емоцій» (за К. Ізардом); «Визначення рівня своєї самооцінки» (за Г. М. Казанцевою).

Обговорення результатів. Проаналізувавши результати респондентів відповідно до специфіки їхньої трудової діяльності за шкалою стресостійкості, ми виявили, що досліджувані, які працюють із людьми, демонструють найвищий рівень стресостійкості (найнижчий показник схильності до стресу) (Хсер=18,14), порівняно 3 іншими. Найнижчий рівень стресостійкості спостерігаємо в діагностованих, котрі працюють із документами $(\mathrm{Xcep}=25,4)$, що також можна пояснити специфікою роботи цієї категорії працівників.

Для осіб, професійна діяльність яких пов'язана 3 опрацюванням великої кількості документів, характерні високі показники деперсоналізації (Хсер=9,33) та редукції професійних досягнень $($ Хсер=33,25) і середні показники емоційного виснаження (Хсер=17,25). Відповідно, особам, професійна діяльність яких пов'язана з людьми, властиві найвищий рівень деперсоналізації $(\mathrm{Xcep}=9,35)$ і середній рівень емоцій-

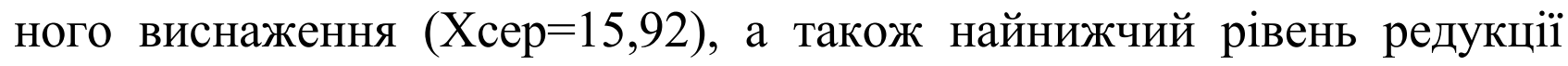


професійних досягнень (Хсер=29). Для осіб, у професійній діяльності котрих поєднуються різні види робіт (змішана група), характерні найвищий рівень емоційного виснаження (Хcep=19,2), середній рівень деперсоналізації $(X c e p=9,14)$ та редукції професійних досягнень

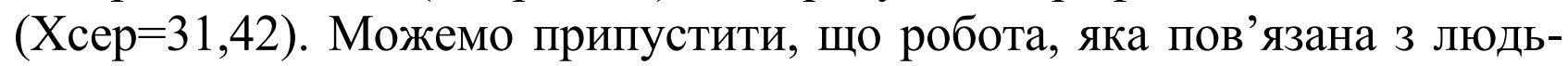
ми, а також опрацюванням документів й інформації, характеризуються напруженістю та стресогенністю й сприяє емоційному виснаженню та професійному вигоранню працівника. Працівники, які обіймають керівні посади різного спрямування, демонструють високий рівень редукції

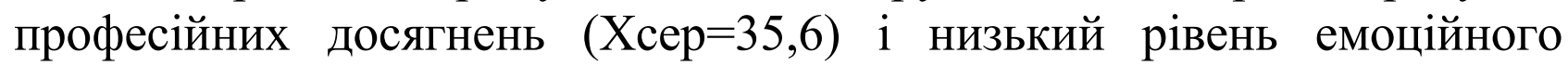

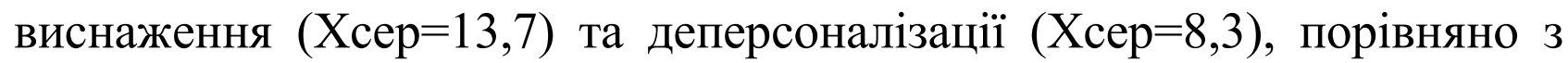
іншими групами.

Щодо рівня вираженості емоційних переживань відповідно до специфіки роботи нами виявлено, що в осіб, які працюють із людьми, спостерігаємо найвищий показник переживання позитивних емоцій $(\mathrm{Xcep}=28,5)$, дещо нижчі показники в тих, котрі працюють із документами (Хсер=27,16), та осіб, діяльність яких поєднує різні види робіт (змішана) (Хсер=24,35). Найнижчі показники демонструють індивіди, котрі займають керівні посади (Хсер=22,1).

Проаналізувавши результати за шкалою «негативні емоції», ми бачимо, що в осіб, які працюють із документами, спостерігаємо найвищий показник переживання негативних емоцій $(\mathrm{Xcep=19,66).} \mathrm{Дещо}$ нижчі показники в людей, котрі працюють на керівних посадах $(\mathrm{Xcep=16,9).} \mathrm{Найнижчі} \mathrm{показники} \mathrm{демонструють} \mathrm{особи,} \mathrm{які} \mathrm{працюють}$ iз людьми $(\mathrm{Xcep=13,28)} \mathrm{та} \mathrm{діяльність} \mathrm{яких} \mathrm{поєднує} \mathrm{різні} \mathrm{види} \mathrm{робіт}$ (змішана) (Хсер=13,64).

Проаналізувавши результати за шкалою «тривожно-депресивні емоції», ми бачимо, що в людей, котрі працюють із документами, спостерігаємо найвищий показник переживання тривожно-депресивних емоцій $(\mathrm{Xcep=19,66).} \mathrm{Дещо} \mathrm{нижчі} \mathrm{дані} \mathrm{в} \mathrm{осіб,} \mathrm{які} \mathrm{працюють} \mathrm{на}$ керівних посадах $(X c е p=14,4)$, й осіб, котрі працюють із людьми $(\mathrm{Xcep}=11,71)$. Найнижчі показники демонструють особи, які працюють із людьми та діяльність яких поєднує різні види робіт (змішана) $(\mathrm{Xcep}=10,85)$.

В осіб, котрі працюють із людьми, спостерігаємо навищий показник переживання позитивних емоцій, для них характерні підвищений настрій та оптимізм. А особи, які працюють із документами, демонструють найвищий рівень переживань негативних і тривожно- 
депресивних емоцій, вони гостро та негативно реагують на незначні перешкоди чи невдачі.

Отримані результати свідчать про відсутність значних відмінностей у самооцінці досліджуваних.

Для встановлення взаємозв'язку між емпіричними референтами емоційної безпеки нами використано процедуру кореляційного аналізу за коефіцієнтом кореляції r-Пірсона.

Значущі кореляційні зв’язки між показниками базових емоцій i даними професійного вигорання й самооцінки відображені в табл. 1.

Таблиия 1

Кореляційні зв'язки між показниками базових емоцій та даними професійного вигорання (емоційне виснаження, деперсоналізація, редукція професійних досягнень) і рівнем самооцінки

\begin{tabular}{|c|c|c|c|c|}
\hline \multirow[t]{2}{*}{ Базові емоції } & \multicolumn{3}{|c|}{ Професійне вигорання } & \multirow[t]{2}{*}{ Самооцінка } \\
\hline & $\begin{array}{c}\text { емоційне } \\
\text { виснаження }\end{array}$ & деперсоналізація & $\begin{array}{c}\text { редукція } \\
\text { професійних } \\
\text { досягнень }\end{array}$ & \\
\hline 1 - інтерес & $0,114 * *$ & $0,068 * *$ & $0,305 * *$ & $0,11 *$ \\
\hline 2 - радість & $-0,137 *$ & $0,052 *$ & $0,205^{*}$ & $0,10 * *$ \\
\hline 3 - здивування & $-0,179 * *$ & $-0,015^{*}$ & $0,238 * *$ & $0,12 *$ \\
\hline $4-$ горе & $0,399 *$ & $0,171 * *$ & $-0,001$ & $-0,186 * *$ \\
\hline $5-$ гнів & $-0,052$ & $-0,053 * *$ & $0,091 * *$ & $-0,264 *$ \\
\hline 6 - відраза & $0,057 *$ & $-0,065^{*}$ & $-0,010 * *$ & $-0,267 *$ \\
\hline 7 - презирство & $0,031 *$ & $-0,113 *$ & $0,030 *$ & $-0,147 * *$ \\
\hline 8 - страх & $0,083^{*}$ & $-0,057 *$ & $0,098 *$ & $-0,282 *$ \\
\hline 9 - сором & $0,227 * *$ & $0,029 *$ & $0,125^{*}$ & $-0,282 * *$ \\
\hline 10 - провина & $0,045^{*}$ & $-0,111 * *$ & 0,073 & $0,247^{*}$ \\
\hline
\end{tabular}

Примітка. ${ }^{*} \mathrm{p}<0,05,{ }^{* *} \mathrm{p}<0,01$.

За $<<0,01$ рівень статистичної значущості перебуває в межах $1 \%$ похибки, за $\mathrm{p}<0,05$-у межах $5 \%$ похибки. 
Зазначимо, що характер кореляційних зв'язків між показниками базових емоцій і рівнем професійного вигорання та самооцінки в досліджуванних засвідчив, що між базовими емоція, зокрема такими, як горе, гнів, сором, провина, відраза, презирство, та емоційним виснаженням, деперсоналізацією й редукцією професійних досягнень існує статистично значущий зв'язок, що свідчить про те, що переживання негативних емоцій мають істотний вплив на рівень професійного вигорання, ставлення до колег, до професійної діяльності та на загальний емоційних фон досліджуванних.

Зокрема, наявний прямий позитивний зв'язок між такими показниками, як горе, страх, інтерес, сором, та емоційним виснаженням; горем і деперсоналізацією; інтересом, здивуванням, страхом, соромом i редукцією професійних досягнень, що вказує на однонаправлену динаміку параметрів. Збільшення одного параметра зумовлює збільшення іншого, тобто переживання таких емоцій, як гнів, горе, страх сором, впливає на виникнення емоційного виснаження, знецінення професійних умінь та навичок, а також негативне ставлення до оточення.

Негативний зворотний зв'язок спостерігаємо між такими показниками, як інтерес, радість, здивування й емоційне виснаження; провина та деперсоналізація, що вказує на різнонаправлену динаміку параматрів - збільшення одного параметра зумовлює зменшення іншого. За збільшення переживань таких емоцій, як радість, інтерес, здивування, зменшується рівень емоційного виснаження, байдужості, утоми, емоційного перенасичення й навпаки.

Також згідно з результатами кореляційного аналізу виявлено, що між показникими базових емоцій та самооцінкою також спостерігаємо статистично значущий зв'язок, зокрема, між такими показниками, як гнів, сором, відраза, презирство, страх і провина. Це свідчить про те, що рівень самооцінки залежить та корелює 3 рівнем вираженості описанах емоційних переживань, які $є$ негативно забарвленими: чим більший рівень переживань емоцій, тим нижчий рівень самооцінки, самоставлення, упевненості в собі та своїх можливостях. Якщо ж для досліджуванних характерний низький рівень переживань негативних емоцій то, відповідно, і рівень самооцінки та прийняття себе буде високим.

Отже, показники вираженості базових емоційних переживань тісно корелюють із компоненами професійного вигорання, а також із рівнем самооцінки. 
Таблиия 2

Значущі кореляційні зв'язки між показниками професійного вигорання (емоційне виснаження, деперсоналізація, редукція професійних досягнень) та стресостійкістю й рівнем самооцінки

\begin{tabular}{|l|c|c|}
\hline \multicolumn{1}{|c|}{$\begin{array}{c}\text { Шкали професійного } \\
\text { вигорання }\end{array}$} & Стресостійкість & Самооцінка \\
\hline Емоційне виснаження & $0,178^{*}$ & $-0,162 *$ \\
\hline Деперсоналізація & $0,029 *$ & $-0,243 * *$ \\
\hline Редукція професіних досягнень & $0,059 * *$ & $-0,076^{*}$ \\
\hline
\end{tabular}

Примітка. ${ }^{*} \mathrm{p}<0,05,{ }^{* *} \mathrm{p}<0,01$.

За $\mathrm{p}<0,01$ рівень статистичної значущості перебуває в межах $1 \%$ похибки, за р $<0,05$ перебуває в межах 5 \% похибки.

Як видно з табл. 2, між емоційним виснаженням і стресостійкістю існує прямий позитивний кореляційний зв'язок, що вказує на те, що ці показники $є$ взаємозалежними: чим вищий рівень схильності до стресу, тим більший рівень емоційного виснаження. Між показниками деперсоналізації та редукції прфесійних досягнень і схильності до стресу наявний слабкий кореляційний зв'язок; між показниками емоційного виснаження, деперсоналізації, редукції професійних досягнень та самооцінкою спостерігаємо негативний зворотний зв'язок.

Також потрібно зазначити, що з результатів кореляційного аналізу ми чітко простежуємо значний зворотний кореляційний звя'зок між рівнем схильності до стресу й рівнем самооцінки, $(-0,411 ; \mathrm{p}<0,05)$, що свідчить: чим вищий рівень самооцінки, тим нижчий рівень схильності до стресу. Отже, можемо констатувати, що рівень схильності до стресу тісно пов'язаний із самооцінкою, а професійне вигорання пов'язане 3 рівнем схильності до стресу та самооцінкою.

Висновки й перспективи. Отже, проведене теоретичне та емпіричне дослідження дає підстави стверджувати, що емоційну безпеку особистості професіонала можна визначити як почуття впевненості щодо володіння внутрішніми психологічними ресурсами для протистояння загрозам і небезпекам, пов'язаним із професійною діяльністю.

Емоційна безпека професіонала на індивідуально-психологічному рівні може бути визначена через низьку схильність до стресу, 
адекватний рівень самооцінки, переважання позитивних емоцій та низький рівень професійного вигорання.

Проаналізувавши дані відповідно до специфіки роботи, ми побачили що досліджувані, які працюють із людьми, демонструють найвищий рівень стресостійкості. Найнижчий рівень стресостійкості спостерігаємо в діагностованих, які працюють із документами. Для осіб, професійна діяльність, яких пов'язана $з$ людьми, характерний найвищий рівень деперсоналізації, але простежено найнижчий рівень редукції професійних досягнень. В осіб, у професійній діяльності котрих поєднуються різні види робіт (змішана група), помічаємо найвищий рівень емоційного виснаження, а працівники, які обіймають керівні посади різного спрямування, демонструють високий рівень редукції професійних досягнень. Аналізуючи рівень вираженості емоційних переживань, ми виявили, що в осіб, котрі працюють із людьми, спостерігаємо найвищий показник переживання позитивних емоцій, а в тих, які працюють із документами, - найвищий рівень переживань негативних і тривожно-депресивних емоцій.

Установлено значимі статистичні взаємозв'язки між показниками базових емоцій та даними професійного вигорання (емоційне виснаження, деперсоналізація, редукція професійних досягнень) і рівнем самооцінки та між показниками професійного вигорання й стресостійкістю та рівнем самооцінки працівників комерційної організації.

Подальше вивчення феномену емоційної безпеки особистості професіонала вбачаємо в контексті організаційного середовища й міжособистісної взаємодії персоналу організації. Важливе завдання та виклик для організаційних психологів сьогодні - віднайдення ефективних інструментів і програм забезпечення емоційної стабільності й безпеки персоналу на робочому місці, що, безумовно, є перспективним напрямом подальших досліджень.

\section{Лiтература}

1. Bar-Tal, D., \& Jacobson, D. (1998). A psychological perspective on security. Applied Psychology: An International Review, 47(1), 59-71. DOI: https://doi. org/10.1111/j.1464-0597.1998.tb00013.x

2. Blatz, W. E. (1966). Human security: Some reflections. Toronto: University of Toronto Press.

3. Christopher, J. Collins and Ken, G. Smith (2006). Knowledge Exchange and Combination: The Role of Human Resource Practices in the Performance of High- 
Technology Firms. AMJ, 49, 544-560. DOI: https://doi.org/10.5465/amj.2006.2179 4671

4. Davies, P., Cummings, E. M. (1994). Marital conflict and child adjustment: An emotional security hypothesis. Psychological Bulletin, 116, 387-411.

5. Edmondson, A. (1999). Psychological safety and learning behavior in work teams. Administrative science quarterly, 44(2), 350-383.

6. Edmondson, A. C., \& Lei, Z. (2014). Psychological safety: The history, renaissance, and future of an interpersonal construct. Annual Review of Organizational Psychology and Organizational Behavior, 1(1), 23-43. DOI: https://doi.org/10.1146/ annurev-orgpsych-031413-091305

7. Erikson, E. H. (1968). Identity: Youth and crisis. New York: Norton.

8. Leroy, H., Dierynck, B., Anseel, F., Simons, T. (2012). Behavioral integrity for safety, priority of safety, psychological safety, and patient safety: A team-level study. Journal of Applied Psychology, 97(6), 1273-1281.

9. Little, M., Kobak, R. (2003). Emotional security with teachers and children's stress reactivity: A comparison of special-education and regular-education classrooms. Journal of Clinical Child \& Adolescent Psychology, 32, 127-138.

10. Baer, M., Frese, M. (2003). Innovation is not enough: Climates for initiative and psychological safety, process innovations, and firm performance. Journal of Organizational Behavior, 24, 1, 45-68.

11. May, D. R. (2004). The psychology condition of meaningfulness, safety and availability and the engagement of the human spirit at work. Journal of Occupational and Organizational Psychology, № 77, 11-37.

12. Mikulincer, M. (1998). The relationship between adult attachment styles andemotional and cognitive reactions to stressful events. In J. A. Simpson \& W. S. Rholes (Eds.). Attachment Theory and Close Relationships. New York: Guilford Press, 143-165.

13. Law, R., Dollard, M., Tuckey, M. Dormann, C. (2011). Psychosocial safety climate as a lead indicator of workplace bullying and harassment, job resources, psychological health and employee engagement. Accident Analysis \& Prevention, 43(5), 1782-1793.

14. Toffler, A. (1965). The Future as a Way of Life. Horizon magazine, VII (3).

15. Агузумцян, Р. В. (2009). Психологические аспекты безопасности личности. Вестник практической психологии образования, 2 (19), 40-44.

16. Бек, У. (2000). Общество риска. На пути к другому модерну. Москва: Прогресс-Традиция, 384 с.

17. Блинова, О. Є., Каленчук, В. О. (2018). Особистісні чинники психологічної безпеки студентів закладів вищої освіти. Науковий вісник ХДУ. Серія: Психологічні науки, 5, 154-160.

18. Закс, Л. А. (2012). Человек в условиях комплексных угроз личной безопасности. Наука и современность, 18, 142-147.

19. Зотова, О. Ю. (2011). Социально-психологическая безопасность личности. Автореф. дис. на соискание ученой степени д-ра психол. наук. Москва. 
20. Лазорко, О. В. (2016). Психологія професійної безпеки особистості. Луцьк: Вежа-Друк.

21. Приходько, I. I. (2013). Засади психологічної безпеки персоналу екстремальних видів діяльності: монографія. Харків: Акад. ВВ МВС України, $745 \mathrm{c}$.

22. Рубцов, С., Березина, Т. Н. (2013). Роль подлинных эмоций в эмоциональной безопасности образовательной среды. Психологическая наука $u$ образование, 6, 101-107.

23. Харченко, А. С. (2012). Психологічна безпека особистості викладача вишу. Науковий вісник Львівського державного університету внутрішніх справ, $2(2), 443-450$.

\section{References}

1. Bar-Tal, D., \& Jacobson, D. (1998). A psychological perspective on security. Applied Psychology: An International Review, 47(1), 59-71. DOI: https://doi. org/10.1111/j.1464-0597.1998.tb00013.x

2. Blatz, W. E. (1966). Human security: Some reflections. Toronto: University of Toronto Press.

3. Christopher, J. Collins and Ken, G. Smith (2006). Knowledge Exchange and Combination: The Role of Human Resource Practices in the Performance of HighTechnology Firms. AMJ, 49, 544-560, DOI: https://doi.org/10.5465/amj.2006.21794671

4. Davies, P., Cummings, E. M. (1994). Marital conflict and child adjustment: An emotional security hypothesis. Psychological Bulletin, 116, 387-411.

5. Edmondson, A. (1999). Psychological safety and learning behavior in work teams. Administrative science quarterly, 44(2), 350-383.

6. Edmondson, A. C., \& Lei, Z. (2014). Psychological safety: The history, renaissance, and future of an interpersonal construct. Annual Review of Organizational Psychology and Organizational Behavior, 1(1), 23-43. DOI: https://doi.org/10.1146/ annurev-orgpsych-031413-091305

7. Erikson, E. H. (1968). Identity: Youth and crisis. New York: Norton.

8. Leroy, H., Dierynck, B., Anseel, F., Simons, T. (2012). Behavioral integrity for safety, priority of safety, psychological safety, and patient safety: A team-level study. Journal of Applied Psychology, 97(6), 1273-1281.

9. Little, M., Kobak, R. (2003). Emotional security with teachers and children's stress reactivity: A comparison of special-education and regular-education classrooms. Journal of Clinical Child \& Adolescent Psychology, 32, 127-138.

10. Baer, M., Frese, M. (2003). Innovation is not enough: Climates for initiative and psychological safety, process innovations, and firm performance. Journal of Organizational Behavior, 24, 1, 45-68.

11. May, D. R. (2004). The psychology condition of meaningfulness, safety and availability and the engagement of the human spirit at work. Journal of Occupational and Organizational Psychology, № 77, 11-37. 
12. Mikulincer, M. (1998). The relationship between adult attachment styles andemotional and cognitive reactions to stressful events. In J. A. Simpson \& W. S. Rholes (Eds.). Attachment Theory and Close Relationships. New York: Guilford Press, 143-165.

13. Law, R., Dollard, M., Tuckey, M. Dormann, C. (2011). Psychosocial safety climate as a lead indicator of workplace bullying and harassment, job resources, psychological health and employee engagement. Accident Analysis \& Prevention, 43(5), 1782-1793.

14. Toffler, A. (1965). The Future as a Way of Life. Horizon magazine, VII (3).

15. Ahuzumtsian, R. V. (2009). Psykholohycheskye aspekty bezopasnosty lychnosty. [Psychological aspects of personal safety] Vestnyk praktycheskoi psykholohyy obrazovanyia - Bulletin of practical educational psychology, 2 (19), 4044 (in Russian).

16. Bek, U. (2000). Obshchestvo ryska. Na puty k druhomu modern [Risk society. On the way to another modernity]. Moskva: Prohress-Tradytsyia (in Russian).

17. Blynova, O. Y., Kalenchuk, V. O. (2018). Osobystisni chynnyky psykholohichnoi bezpeky studentiv zakladiv vyshchoi osvity [Individual factors of psychological safety of the students of higher education institutions]. Naukovyi visnyk KhDU Seriia: Psykholohichni nauky - Scientific Bulletin of KSU Series Psychological Sciences, 5, 154-160 (in Ukrainian).

18. Zaks, L. A. (2012). Chelovek v uslovyiakh kompleksnykh uhroz lychnoi bezopasnosty [A person in conditions of complex threats to personal safety]. Nauka $y$ sovremennost - Science and modernity, 18, 142-147 (in Russian).

19. Zotova, O. Y. (2011). Sotsyalno-psykholohycheskaia bezopasnost lychnosty [Socio-psychological security of the individual]. Extended abstract of Doctor's thesis. Moskva (in Russian).

20. Lazorko, O. V. (2016). Psykholohiia profesiinoi bezpeky osobystosti [Psychology of professional security of the individual]. Lutsk: Vezha-Druk (in Ukrainian).

21. Prykhodko, I. I. (2013). Zasady psykholohichnoi bezpeky personalu ekstremalnykh vydiv diialnosti [Principles of psychological safety of personnel of extreme activities]. Kharkiv: Akad. VV MVS Ukrainy (in Ukrainian).

22. Rubtsov, S., Berezyna, T. N. (2013). Rol podlynnykh emotsyi v emotsyonalnoi bezopasnosty obrazovatelnoi sredy [The role of genuine emotions in the emotional security of the educational environment]. Psykholohycheskaia nauka $y$ obrazovanye - Psychological Science and Education, 6, 101-107 (in Russian).

23. Kharchenko, A. S. (2012). Psykholohichna bezpeka osobystosti vykladacha vyshu [Psychological security of the university teacher's personality.]. Naukovyi visnyk Lvivskoho derzhavnoho universytetu vnutrishnikh sprav - Scientific Bulletin of Lviv State University of Internal Affairs, 2 (2), 443-450 (in Ukrainian).

Received: 08.09.2020

Accepted: 03.10.2020 